\title{
INTEGRASI NILAI-NILAI KARAKTER MATEMATIKA MELALUI PEMBELAJARAN KONTEKSTUAL
}

\section{ThE INTEGRATION OF MATHEMATICAL ChaRACTER VALUE THROUGH CONTEXTUAL LEARNING}

\author{
Iyam Maryati ${ }^{1}$ dan Nanang Priatna ${ }^{2}$
}

1 Mahasiswa S3 Program Studi Pendidikan Matematika, Universitas Pendidikan Indonesia Bandung, Jawa Barat, Indonesia maryati_iyam@student.upi.edu

\author{
2 Program Studi Pendidikan Matematika, Universitas Pendidikan Indonesia \\ Bandung, Jawa Barat, Indonesia \\ nanang_priatna@yahoo.com
}

\begin{abstract}
Abstrak
Pendidikan karakter merupakan upaya untuk meningkatkan kualitas proses dan hasil pembelajaran yang mengarah kepada pembentukan karakter peserta didik dengan menitiberatkan pada keteladanan, pembiasaan, dan penciptaan lingkungan yaang kondusif . Bertujuan untuk menanamkan nilai-nilai karakter matematika seperti jujur, demokrasi, bertanggungjawab, mandiri, disiplin, kerja keras, kreatif, dan rasa ingin tahu. Nilai-nilai karakter yang dikembangkan dalam pembelajaran matematika tetap harus berlandaskan pada nilai-nilai universal. Pengintegrasian nilai-nilai pendidikan karakter dapat ditempuh dengan langkahlangkah : a) Menggunakan nilai-nilai budaya dan karakter yang memperlihatkan keterkaitan antara Kompetensi Inti dan Kompetensi Dasar dengan nilai dan indikator untuk menentukan nilai yang akan dikembangkan; b) Mencantumkan nilai-nilai budaya dan karakter itu ke dalam silabus; c) Mencantumkan nilai-nilai yang sudah tertera pada silabus ke dalam Rencana Pelaksanaan Pembelajaran; d) Mengembangkan proses pembelajaran peserta didik secara aktif yang memungkinkan peserta didik memiliki kesempatan melakukan internalisasi nilai dan menunjukkannya dalam perilaku yang sesuai; e) Memberikan bantuan kepada peserta didik, baik yang mengalami kesulitan untuk menginternalisasi nilai maupun untuk menunjukkannya dalam perilaku. Oleh karena itu diharapkan setiap peserta didik mampu menginternalisasikan nilai-nilai tersebut ke dalam tingkah laku kehidupan sehari-hari melalui proses pembelajaran, baik di dalam kelas maupun di luar kelas. Pembelajaran yang dapat menginternalisasikan nilai-nilai tersebut adalah pembelajaran kontekstual yang membantu guru dalam memotivasi siswa untuk mengaitkan pengetahuan yang dipelajarinya dengan kehidupan sehari-hari. Karakter apa sajakah yang dapat dikembangkan pada mata pelajaran matematika?. Dan model pembelajaran apa yang dapat diterapkan untuk mengembangkan karakter matematika?. Dengan menggunakan metode penelusuran literatur, artikel ini menyajikan tentang integrasi nilai-nilai karakter dalam mata pelajaran matematika melalui model pembelajaran kontekstual.

Kata Kunci: Nilai-Nilai karakteristik Matematika, Pembelajaran Kontekstual.
\end{abstract}

\begin{abstract}
Character education is an effort to improve the quality of process and learning outcomes that lead to the formation of the character of learners by focusing on exemplary, habituation, and the creation of a conducive environment. Aims to inculcate the values of mathematical characters such as honest, democratic, responsible, independent, disciplined, hard work, creative, and curiosity. The character values developed in mathematics learning must still be based on
\end{abstract}


universal values. Integrating character education values can be pursued by the following steps: a) Using cultural values and characters that show the linkage between Core Competence and Basic Competence with values and indicators to determine the value to be developed; b) Include the cultural and character values into the syllabus; $c$ ) Include the values listed in the syllabus into the Lesson Plans; d) Develop an active learning process of learners that enable learners to have opportunities to internalize values and demonstrate them in appropriate behaviors; e) Provide assistance to learners, whether it is difficult to internalize the value or to show it in behavior. Therefore it is expected that every student can internalize these values into the behavior of everyday life through the learning process, both in the classroom and outside the classroom. Learning that can internalize these values is contextual learning that helps teachers in motivating students to relate knowledge learned to everyday life. What are the characteristics that can be developed on math subjects ?. And what learning model can be applied to develop math character ?. Using the literature search method, this article presents the integration of character values in mathematics subjects through a contextual learning model.

Keyword: Values of Mathematical Characteristics, Contextual Learning.

\section{Pendahuluan}

Karakter merupakan fondasi utama dalam membangun sebuah bangsa yang besar. Untuk menjadi bangsa yang besar diperlukan sebuah proses yang melibatkan banyak pihak. Pendidikan memiliki peranan yang sangat strategis dalam membentuk karakter bangsa. Karena dengan pendidikan kualitas sumber daya manusia sebagai penggerak roda pembangunan bangsa dapat ditingkatkan. Tanpa pendidikan yang berkualitas sangat tidak mungkin tujuan pembangunan nasional dari suatu negara dapat tercapai dengan baik. pendidikan yang pertama dan paling utama bermula dari keluarga, karena seorang anak mulai mengenal lingkungan pertamanya adalah keluarga. Sehingga kebiasaan dalam keluarga merupakan input dalam pembentukan kepribadian. Kepribadiaan seseorang ini lambat laun akan membentuk suatu karakter. Pendidikan sangat erat sekali kaitannya dengan pembentukan karakter, apabila karakter yang dibangun oleh setiap keluarga dapat dilakukan dengan baik maka karakter bangsa ini akan terbangun pula dengan baik. Oleh karena itu peran keluarga dalam pendidikan karakter sangatlah penting dan menjadikan pendidikan anak sebagai fokus perhatiannya. Dengan demikian karakter merupakan sifat alami seseorang dalam merespons keadaan atau masalah seharihari dengan tingkah laku yang baik. Hal ini sejalan dengan yang dikemukakan oleh Aristoteles, bahwa karakter sangat berkaitan erat dengan "habit" atau kebiasaan yang terus menerus dilakukan.

Lingkungan sekolah merupakan institusi pendidikan yang sangat penting perananya dalam mewujudkan tujuan pembangunan bangsa ini. Dalam Undang-Undang Republik Indonesia (Undang-Undang Republik Indonesia Nomor 20 Tahun 2003 Tentang Sistem Pendidikan Nasional) Bab Il Pasal 3: "Pendidikan nasional berfungsi mengembangkan kemampuan dan membentuk watak serta peradaban bangsa yang bermartabat dalam rangka mencerdaskan kehidupan bangsa, bertujuan untuk berkembangnya potensi 
peserta didik agar menjadi manusia yang beriman dan bertakwa kepada Tuhan Yang Maha Esa, berakhlak mulia, sehat, berilmu, cakap, kreatif, mandiri, dan menjadi warga negara yang demokratis serta bertanggung jawab". Dalam mewujudkan tujuan pendidikan nasional tersebut institusi sekolah memiliki peranan yang tidak hanya sebatas transfer ilmu pengetahuan saja tetapi lebih kepada pembiasaan karakter yang baik dan pembinaan peserta didik sebagai generasi penerus keberlangsungan kehidupan bangsa ini. Hal ini Sebagaimana yang diungkapkan oleh Sauri (2010) bahwa proses pembelajaran tidak berhenti pada penyampaian materi kurikulum, tetapi pengembangan reproduksi budaya dan kebiasaan baru yang lebih unggul pun seyogyanya dapat dilakukan. Proses pendidikan tidak hanya mengembangkan kecerdasan intelektual saja tetapi harus mengembangkan kecerdasan emosi, sosial, dan spiritual yang akhirnya akan membentuk karakter peserta didik yang memiliki kecerdasan yang paripurna. Sehingga di masa yang akan datang bangsa ini dapat dipimpin oleh orang-orang yang memiliki integritas dan loyalitas yang tinggi terhadap bangsa ini.

Pada saat ini bangsa Indonesia sedang mengalami degradasi moral yang dapat dilihat dari perilaku semua kalangan masyarakat yang lebih mengedepankan aspek emosi pribadi tanpa memperhatikan aspek sosial yang dapat memberikan manfaat bagi kehidupan masyarakat yang lainnya. Indonesia hari ini ditandai dengan krisis multidimesi yang antara lain tercermin dalam perilaku masyarakat yang menjadi lebih korup, masyarakat awam yang lebih rapuh dan menjadi kehilangan arah, mudah goyah dan tanpa orientasi, mendemonstrasikan sikap anti sosial, anti kemapanan, beringas, dan kehilangan keseimbangan antara rasio dan emosinya (Sumantri, 2010). Karakter yang diwariskan oleh leluhur bangsa ini yang terkenal dengan sikap gotong royong, tepa selira (tenggang rasa), dan silih asah asih dan asuh (saling menyayangi dan mengayomi) ini sedikit demi sedikit telah berubah menjadi mudah marah, kurang peduli terhadap sesama, beringas, dan lebih mengedepankan kepentingan pribadi daripada kepentingan bangsa.

Indikator lain yang nampak dalam kehidupan sehari-hari sebagai gejala rusaknya karakter bangsa yaitu dapat dilihat dari sopan santun peserta didik yang sudah memudar dalam kehidupan bermasyarakat. Tingkah laku mereka baik kepada guru, orang tua atau dengan teman-temannya seringkali tidak menunjukkan sebagai seorang yang terpelajar. Hal ini sependapat dengan Isnaini yang menyatakan bahwa rusaknya karakter generasi bangsa seperti cara berbicara baik diantara sesama mereka maupun kepada guru atau orang tua, baik di lingkungan sekolah maupun di masyarakat yang tidak sepantasnya mereka ucapkan seringkali terlontar. Selain itu apa yang diungkapkan oleh [5] Krisis yang melanda pelajar (juga elite politik) mengindikasikan bahwa pendidikan agama dan moral yang didapat 
di bangku sekolah, tidak berdampak terhadap perubahan perilaku manusia Indonesia. Bahkan yang terlihat adalah begitu banyak manusia Indonesia yang tidak koheren antara ucapan dan tindakannya. Kondisi demikian, diduga berawal dari apa yang dihasilkan oleh dunia pendidikan.

Dengan melihat fenomena di atas, pendidikan karakter merupakan salah satu solusi untuk mengatasi masalah degradasi moral yang tengah menimpa bangsa ini. Pengembangan Pendidikan budaya dan karakter secara terintegrasi dalam proses pembelajaran berupa pengenalan nilainilai melalui fasilitas yang diperolehnya secara sadar akan pentingnya nilai-nilai dalam kehidupan, dan penginternalisas ian nilai-nilai ke dalam tingkah laku siswa sehari-hari melalui proses pembelajaran baik yang berlangsung di dalam maupun di luar kelas pada semua mata pelajaran. Hal tersebut tercantum dalam Panduan Pendidikan Karakter di SMP (Kementrian Pendidikan nasional., 2011) Matematika merupakan mata pelajaran yang wajib diikuti oleh semua peserta didik dari Sekolah Dasar sampai dengan Sekolah Menengah Atas, dalam proses pembelajarannya harus dapat melahirkan karakter matematika yang sangat bermanfaat terhadap pembentukan karakter bangsa. Karakter apa sajakah yang dapat dikembangkan pada mata pelajaran matematika?. Dan model pembelajaran apa yang dapat diterapkan untuk mengembangkan karakter matematika. Dengan menggunakan metode penelusuran literatur, artikel ini menyajikan tentang integrasi nilai-nilai karakter dalam mata pelajaran matematika melalui model pembelajaran kontekstual.

\section{KAJIAN TEORI}

\section{A. Nilai-nilai Karakter dalam Mata Pelajaran Matematika}

Nilai-nilai karakter yang dapat dikembangkan dalam mata pelajaran matematika adalah nilai-nilai positif yang tidak terlepas dari hakikat maematika itu sendiri. Matematika merupakan ilmu deduktif karena dalam proses mencari kebenaran harus dibuktikan dengan menggeneralisasi sifat, teorema, atau dalil setelah dibuktikan secara deduktif. Matematika merupakan ilmu pengetahuan yang diperoleh dengan bernalar yang menggunakan istilah yang didefinisikan dengan cermat, jelas, dan akurat, representasinya dengan lambang-lambang atau simbol dan memiliki arti serta dapat digunakan dalam pemecahan masalah yang berkaitan dengan bilangan. Adapun Hakikat dari mattematika yaitu a) Matematika pelajaran tentang suatu pola/ susunan dan hubungan, b) Matematika adalah cara berfikir, c) Matematika adalah Bahasa, d) Matematika adalah suatu alat, e) Matematika adalah suatu seni.

Proses pembelajaran pada dasarnya merupakan rangkaian kegiatan yang dilaksanakan oleh guru sebagai pendidik dan siswa sebagai anak didik dalam kegiatan pengajaran dengan menggunakan sarana dan fasilitas 
pendidikan yang ada untuk mencapai tujuan yang telah ditetapkan dalam kurikulum. (Depdiknas, 2006) Permendiknas nomor 22 tahun 2006 tentang Standar Isi mata Pelajaran Matematika, menyatakan bahwa mata pelajaran matematika bertujuan agar peserta didik memiliki kemampuan sebagai berikut. 1) Memahami konsep matematika, menjelaskan keterkaitan antar konsep atau algoritma secara luwes, akurat, efisien, dan tepat dalam pemecahan masalah. 2) Menggunakan penalaran pada pola dan sifat, melakukan manipulasi matematika dalam membuat generalisasi, menyusun bukti, atau menjelaskan gagasan dan pernyataan matematika. 3) Memecahkan masalah yang meliputi kemampuan memahami masalah, merancang model matematika, menyelesaikan model dan menafsirkan solusi yang diperoleh. 4) Mengomunikasikan gagasan dengan simbol, tabel, diagram, atau media lain untuk memperjelas keadaan atau masalah. 5) Memiliki sikap menghargai kegunaan matematika dalam kehidupan, yaitu memiliki rasa ingin tahu, perhatian, dan minat dalam mempelajari matematika, serta sikap ulet dan percaya diri dalam pemecahan masalah. Sedangkan menurut [8] menyatakan bahwa secara umum, tujuan diberikannya matematika di sekolah adalah untuk membantu siswa mempersiapkan diri agar sanggup menghadapi perubahan keadaan di dalam kehidupan dan di dunia yang selalu berkembang, melalui latihan bertindak atas dasar pemikiran secara logis, rasional dan kritis, serta mempersiapkan siswa agar dapat mempergunakan matematika dan pola pikir matematika dalam kehidupan sehari-hari dan dalam mempelajari berbagai ilmu pengetahuan. Tujuan pendidikan matematika di sekolah lebih ditekankan pada penataan nalar, dasar dan pembentukan sikap, serta keterampilan dalam penerapan matematika.

Ada beberapa nilai karakter yang dapat dikembangkan melalui pembelajaran matematika: 1) Karakter disiplin dalam belajar matematika adalah seseorang diharapkan mampu bekerja secara teratur dan tertib dalam menggunakan aturanaturan dan konsep-konsep. 2) Karakter jujur dapat membentuk jiwa seseorang, bahwa seseorang tidak akan mudah percaya pada isu-isu yang tidak jelas sebelum ada pembuktian. 3) Karakter kerja keras dapat membentuk sikap tidak mudah menyerah terus berjuang untuk menghasilkan suatu jawaban yang benar. dalam menggunakan aturan-aturan dan konsep-konsep. Dalam matematika konsep-konsep tersebut tidak boleh dilanggar karena dapat menimbulkan salah arti. 4) Karakter kreatif dalam menyelesaikan persoalan akan terbiasa memunculkan ide yang kreatif yang dapat membantunya menjalani kehidupan secara lebih efektif dan efisien. 5) Memunculkan rasa ingin tahu dalam matematika akan mengakibatkan seseorang terus belajar dalam sepanjang hidupnya, terus berupaya menggali 
informasi-informasi terkait lingkungan di sekitarnya, sehingga menjadikannya kaya akan wawasan dan ilmu pengetahuan. Rasa ingin tahu membuat seseorang mampu menelaah keterkaitan, perbedaan dan analogi, sehingga diharapkan mampu menjadi a good problems solver (mampu menyelesaikan masalah dengan baik), 6) Karakter mandiri dalam menghadapi tantangan, berbagai permasalahan yang menuntut kita untuk menemukan solusi atau penyelesaiannya. Untuk itu peserta didik harus mampu memiliki sikap yang tidak mudah bergantung pada orang lain, namun berupaya secara mandiri untuk menyelesaikan tugas-tugas yang dihadapi dengan baik, 7) Komunikatif karrena matematika merupakan suatu bahasa, sehingga seseorang harus mampu mengkomunikasikannnya baik secara lisan maupun tulisan, sehingga informasi yang disampaikan dapat diketahui dan dipahami oleh orang lain. 8) Kebiasaan disiplin dalam bernalar yang terbentuk dalam mempelajari matematika melahirkan suatu sikap tanggung jawab atas pelaksanaan kewajiban yang seharusnya dilakukan, baik tanggung jawab terhadap diri sendiri, masyarakat, negara dan Tuhan Yang Maha Esa (Depdiknas, 2006).

\section{B. Pembelajaran Kontekstual}

Pembelajaran kontekstual telah berkembang di negara-negara maju dengan berbagai nama. Di negeri Belanda berkembang dengan nama Realistic Mathematics Education (RME) yang menjelaskan bahwa pembelajaran matematika harus dikaitkan dengan kehidupan nyata siswa. Di Amerika Serikat berkembang dengan nama Contextual Teaching and Learning (CTL) yang intinya membantu guru untuk mengaitkan materi pelajaran dengan kehidupan nyata dan memotivasi siswa untuk mengaitkan pengetahuan yang dipelajarinya dengan kehidupan mereka. Sementara itu di Michigan juga berkembang dengan Connected Mathematics Project (CMP) yang bertujuan mengintegrasikan ide matematika ke dalam konteks kehidupan nyata dengan harapan siswa dapat memahami apa yang dipelajarinya dengan baik dan mudah. Defenisi pembelajaran yang ditulis oleh Johnson (2002) merumuskan pengetahuan CTL sebagai berikut:

"The CTL is an educational process that aims to helps students see meaning in the academic material they are studying by connecting academic subjects with the context of their daily lives, that is, with the context of their personal, social, and cultural circumstances. To achievethis aim, the system encompasses the following eight components: making meaningful connections, doing significant work, selfregulated learning, collaborating, sritical and creative thinking, nurturing the individual, reaching high standards, using authentic assessment".

Kutipan di atas mengandung arti bahwa sistem CTL merupakan suatu proses pendidikan yang bertujuan membantu siswa melihat makna dalam bahan pelajran yang mereka pelajari dengan cara menghubungkannya dengan konteks 
sehari-hari, yaitu dengan konteks menyatakan bahwa kerjasama adalah

lingkungan pribadi, sosial dan budaya. Untuk mencapai tujuan tersebut, sistem CTL akan menuntun siswa melalui delapan prinsip utama CTL yaitu: melakukan hubungan yang bermakna, mengerjakan pekerjaan yang berarti, mengatur cara belajar sendiri, bekerja sama, berpikir kritis dan kreatif, memelihara/ merawat pribadi siswa, mencapai standar yang tinggi, dan menggunakan asesmen autentik.

Pengintegrasian pendidikan nilai-nilai budaya dan karakter bangsa dalam proses pembelajaran dimulai dengan memilih, mengembangkan, dan melaksnakan kegiatan pembelajaran agar siswa mempraktikkan nilai-nilai karakter yang ditargetkan. Dalam Standar Isi Mata Pelajaran Matematika SMP (Kementian Pendidikan Nasional., 2011) dinyatakan bahwa prinsip-rinsip Contextual Teaching and Learning (CTL) disarankan untuk diaplikakan pada semua tahapan pembelajaran matematika. Jika dicermati muatan suatu proses pembelajaran yang dikelola secara CTL, yaitu adanya kegiatan: (1) konstriktivisme, (2) bertanya, (3) menemukan, (4) masyarakat belajar, (5) pemodelan, (6) refleksi, (7) penilaian yang autentik maka CTL berpotensi besar dapat memfasilitasi terintegrasinya nilai-nilai karakter pada diri siswa.

Dalam pembelajaran kontekstual Peserta didik sebagai makhluk sosial membutuhkan orang lain untuk mendukung keberhasilan hidup mereka, sehingga mereka perlu bekerja sama dengan orang lain. Eliasa (2014) situasi ketika sekelompok orang bekerja sama untuk mencapai tujuan tertentu. Kerjasama (colaboration) berbeda dengan bekerja bersama-sama (work together) dimana beberapa orang bekerja sama dalam tempat yang sama tetapi dengan pekerjaan yang berbeda dan pekerjaan seseorang tidak mempengaruhi pekerjaan lain. Melakukan sesuatu bersama-sama akan mendapatkan hasil yang lebih baik bukan untuk melakukannya sendiri. Demikian pula, terjadi pada sejarah bangsa, setiap pencapaian suatu bangsa hanya dapat dicapai melalui kerjasama. Selain itu dalam pembelajaran kontekstual juga mengutamakan kegiatan inkuiri yang mendorong siswa untuk memahami konsep-konsep matematika yang sesuai dengan pembelajaran konseptual. Hal ini sependapat dengan Simon (2013) yang menyatakan pembelajaran konseptual matematika dapat menggambarkan pendekatan yang muncul untuk instruksi yang ditujukan untuk pemahaman matematika tertentu yang mendorong penciptaan kembali konsep-konsep matematika tanpa tergantung pada keberhasilan siswa memecahkan masalah baru.

Dengan demikian pembelajaran kontekstual merupakan konsep belajar yang membantu guru mengaitkan antara materi yang diajarkan dengan situasi nyata siswa. Selain itu kontekstual membantu para siswa menemukan makna dalam pelajaran mereka dengan cara menghubungkan materi dengan konteks 
kehidupan keseharian. Mereka membuat hubungan-hubungan penting yang menghasilkan makna dengan melaksanakan pembelajaran yang diatur sendiri, bekerja sama, berpikir kritis dan kreatif, menghargai orang lain, mencapai standar tinggi, dan berperan serta dalam tugas-tugas penilaian autentik.

\section{Pembahasan}

\section{A. Integrasi Nilai-nilai Karakter Matematika melalui Pembelajaran Kontekstual}

Mengintegrasikan nilai-nilai karakter pada setiap mata pelajaran degan tujuan untuk menanamkan nilai-nilai pada peserta didik akan pentingnya pendidikan karakter, sehingga diharapkan setiap peserta didik mampu menginternalisasikan nilai-nilai itu ke dalam tingkah laku seharihari melalui proses pembelajaran, baik yang berlangsung di dalam maupun di luar kelas. Pada dasarnya kegiatan pembelajaran, selain untuk menjadikan peserta didik menguasai kompetensi (materi) yang ditargetkan, juga dirancang untuk menjadikan peserta didik mengenal, menyadari/peduli, dan menginternalisasi nilai-nilai dan menjadikannya perilaku nilai-nilai karakter yang dikembangkan dalam pembelajaran matematika tetap harus berlandaskan pada nilai-nilai universal. Melalui kegiatan pembelajaran ini, guru dapat mengembangkan nilai-nilai karakter seperti jujur, demokrasi, bertanggungjawab, mandiri, disiplin, kerjakeras, kreatif, rasa ingin tau dan sebagainya. Pengintegrasian nilai-nilai pendidikan karakter dapat ditempuh dengan langkah-langkah berikut: 1) Mengkaji Standar Kompetensi (SK) dan Kompetensi Dasar (KD) pada Standar Isi (SI) untuk menentukan apakah nilai-nilai budaya dan karakter bangsa yang tercantum itu sudah tercakup di dalamnya; 2) Menggunakan nilai-nilai budaya dan karakter yang memperlihatkan keterkaitan antara SK dan KD dengan nilai dan indikator untuk menentukan nilai yang akan dikembangkan; 3) Mencantumkan nilai-nilai budaya dan karakter itu ke dalam silabus; 4) Mencantumkan nilai-nilai yang sudah tertera dalam silabus ke dalam RPP; 5) Mengembangkan proses pembelajaran peserta didik secara aktif yang memungkinkan peserta didik memiliki kesempatan melakukan internalisasi nilai dan menunjukkannya dalam perilaku yang sesuai; 6) Memberikan bantuan kepada peserta didik, baik yang mengalami kesulitan untuk menginternalisasi nilai maupun untuk menunjukkannya dalam perilaku.

Berbagai upaya dapat dilakukan oleh guru matematika untuk mengembangkan nilai-nilai karakter tersebut. Guru harus dapat menciptakan suasana belajar yang mendukung terlaksananya pendidikan karakter, salah satunya adalah dengan pembelajaran CTL. Melalui pembelajaran ini diharapkan berkembangnya nilai-nilai karakter seperti disiplin, tanggung jawab, rasa ingin tahu, kreatif dan lain-lain. Penanaman karakter ini dilakukan secara terus menerus sehingga diharapkan menjadi suatu kebiasaan. Pengembangan 
nilai-nilai dan indikator pendidikan Matematika dapat diperinci sebagaimana

karakter dalam mata pelajaran pada tabel berikut:

Tabel 1.

Nilai Dan Indikator Penerapan Pendidikan Karakter Pada Proses Pembelajaran Matematika Melalui CTL

\begin{tabular}{|c|c|c|}
\hline $\begin{array}{l}\text { Nilai } \\
\text { Karakter }\end{array}$ & $\begin{array}{l}\text { Proses dan Sikap Guru dalam Mengembangkan karakter } \\
\qquad \text { Siswa }\end{array}$ & $\begin{array}{l}\text { Komponen yang diterapkan } \\
\text { dalam Pembelajaran CTL }\end{array}$ \\
\hline Kejujuran & $\begin{array}{l}\text { 1. Memperingatkan siswa yang mencontek temannya } \\
\text { saat mengerjakan tugas atau saat ulangan/ujian. } \\
\text { 2. Memberikan kesempatan kepada siswa untuk } \\
\text { mengemukakan pendapat tentang suatu pokok diskusi } \\
\text { 3. Larangan membawa fasilitas komunikasi pada saat } \\
\text { ulangan ujian atau pun pada saat pembelajaran. } \\
\text { 4. Transparansi penilaian kelas. }\end{array}$ & $\begin{array}{l}\text { 1. Masyarakat belajar } \\
\text { (Learning Community) } \\
\text { 2. Penilaian autentik } \\
\text { (Authentic Assesment) } \\
\text { 3. Refleksi (Reflection) }\end{array}$ \\
\hline Demokratis & $\begin{array}{l}\text { 1. Mengajak seluruh siswa agar dapat bekerja sama } \\
\text { dalam kelompok tanpa membedakan suku, agama, ras, } \\
\text { golongan,status sosial dan status ekonomi. } \\
\text { 2. Memberikan perhatian yang sama kepada semua } \\
\text { siswa. } \\
\text { 3. Memberi kesempatan kepada siswa untuk berbeda } \\
\text { pendapat } \\
\text { 4. Menghargai pendapat siswa tanpa membedaan suku, } \\
\text { agama, ras, golongan,status sosial, dan status ekonomi. }\end{array}$ & $\begin{array}{l}\text { 1. Masyarakat belajar } \\
\text { (Learning Community) } \\
\text { 2. pemodelan (Modeling) } \\
\text { 3. Refleksi (Reflection) }\end{array}$ \\
\hline
\end{tabular}

1. Guru masuk kelas tepat waktu.

2. Menegur siswa yang melanggar aturan di kelas (seperti makan dalam kelas, berbicara, mengganggu temannya, berkeliaran, dan sebagainya).

1. Pemodelan (Modeling)

Disiplin

3. Mengecek kehadiran siswa.

2. Refleksi (Reflection)

4. Menggunakan seragam guru sesuai aturan.

1. Saat memulai pelajaran, guru menuliskan tujuan pembelajaran/KD dan judul materi yang akan dipelajari.

2. Meminta siswa tidak terburu-buru dalam mengerjakan soal.

Teliti 3. Meminta siswa mengecek kembali lembar jawaban sebelum dikumpulkan.

1. Pemodelan (Modeling)

2. Menyelidiki (Inquiry) refleksi (Reflection)

4. Mengetahui tingkat pemahaman siswa terhadap materi yang sedang diajarkan, jika siswa belum paham diberi motivasi atau pertanyaan-pertanyaan terkait materi.

1. Membiasakan semua siswa mengerjakan semua tugas yang diberikan selesai dengan baik pada waktu yang telah ditetapkan.

2. Mengajak siswa untuk lebih giat belajar.

Kerja keras 3. Memberikan kesempatan kepada siswa untuk mencari informasi, tentang materi pelajaran ke teman, guru

1. Masyarakat belajar (Learning Community)

2. Pemodelan (Modeling)

3. Refleksi (Reflection) ataupun pihak lain.

4. Membiasakan siswa untuk mengutarakan pendapatnya saat diskusi kelas.

1. Mengajukan berbagai pertanyaan berkenaan dengan suatu pokok bahasan untuk memancing gagasan siswa.

Kreatif 2. Pemberian tugas yang menantang munculnya daya pikir kreatif.

3. Menerapkan berbagai metode pembelajaran.

1. Masyarakat belajar
(Learning Community)
2. Konstruktivisme
(Contructivism)
3. Kkegiatan bertanya




\begin{tabular}{|c|c|c|}
\hline & $\begin{array}{l}\text { 4. Menggunakan berbagai alat penilaian. } \\
\text { 5. Menggunakan berbagai media pembelajaran. }\end{array}$ & $\begin{array}{l}\text { (Questioning) } \\
\text { 4. Refleksi (Reflection) }\end{array}$ \\
\hline Mandiri & $\begin{array}{l}\text { 1. Menciptakan suasana kelas yang memberikan } \\
\text { kesempatan kepada siswa untuk bekerja sendiri } \\
\text { 2. Meminta siswa untuk mengerjakan sendiri tugas } \\
\text { individu yang diberikan } \\
\text { 3. Memantau kerja siswa secara mandiri } \\
\text { 4. Memberi kesempatan kepada siswa untuk menentukan } \\
\text { 5elompok diskusinya sendiri } \\
\text { 5. Meminta siswa mengerjakan soal di papan tulis. }\end{array}$ & $\begin{array}{l}\text { 1. Masyarakat belajar } \\
\text { (Learning Community) } \\
\text { 2. Penilaian autentik } \\
\text { (Authentic Assesment) } \\
\text { 3. Pemodelan (Modeling) } \\
\text { 4. Konstruktivisme } \\
\text { (Contructivism) } \\
\text { 5. Menyelidiki (Inquiry) } \\
\text { 6. Kegiatan bertanya } \\
\text { (Questioning) } \\
\text { 7. Refleksi (Reflection) }\end{array}$ \\
\hline $\begin{array}{l}\text { Rasa ingin } \\
\text { tahu }\end{array}$ & $\begin{array}{l}\text { 1. Memberikan kesempatan kepada siswa untuk bertanya } \\
\text { kepada guru atau teman tentang materi matematika. } \\
\text { 2. Mengajukan pertanyaan-pertanyaan terkait materi } \\
\text { 3. Menciptakan suasana kelas yang mengundang rasa } \\
\text { ingin tahu. } \\
\text { 4. Mengajak siswa untuk mencari informasi dari berbagai } \\
\text { sumber }\end{array}$ & $\begin{array}{l}\text { 1. Masyarakat belajar } \\
\text { (Learning Community) } \\
\text { 2. Konstruktivisme } \\
\text { (Contructivism) } \\
\text { 3. Menyelidiki (Inquiry) } \\
\text { 4. Kegiatan bertanya } \\
\text { (Questioning) } \\
\text { 5. Refleksi (Reflection) }\end{array}$ \\
\hline $\begin{array}{l}\text { Tanggung } \\
\text { Jawab }\end{array}$ & $\begin{array}{l}\text { 1. Membiasakan siswa untuk mengerjakan soal latihan } \\
\text { yang diberikan. } \\
\text { 2. Membiasakan siswa untuk berani } \\
\text { mempertanggungjawabkan pendapatnya. }\end{array}$ & $\begin{array}{l}\text { 1. Masyarakat belajar } \\
\text { (Learning Community) } \\
\text { 2. Penilaian autentik } \\
\text { (Authentic Assesment) } \\
\text { 3. Pemodelan (Modeling) } \\
\text { 4. Refleksi (Reflection) }\end{array}$ \\
\hline
\end{tabular}

Pendidikan karakter merupakan usaha yang dilakukan guru untuk membantu siswa dalam menanamkan nilai-nilai karakter. Penanaman pendidikan karakter oleh guru dapat ditunjukkan dengan memberikan keteladanan yang mencerminkan nilai-nilai karakter yang ingin ditanamkan kepada siswa dalam proses pembelajaran. Nilai-nilai karakter yang dapat ditunjukkan oleh guru misalnya datang tepat waktu (disiplin waktu), bekerja keras, sopan, jujur dan lain sebagainya. Sedangkan nilai-nilai karakter siswa dapat dilihat dari berbagai kegiatan siswa misalnya ketika guru memerintahkan siswa mengerjakan soal, siswa terlihat bekerja keras untuk memecahkan soal tersebut. Ketika ada tugas pekerjaan rumah, jika siswa lupa mengerjakan atau mengalami kesulitan maka akan berkata jujur kepada guru. Pendidikan karakter tidak hanya sebatas pada pemberian materi atau pengetahuan saja tanpa adanya pigur atau panutan yang dijadikan contoh, sebagaimana yang diungkapkan Prabowo dan Sidi (2010) pendidikan karakter harus memperhatikan tiga hal yang penting yaitu keteladanan, pembiasaan, dan koreksi atau kontrol.

\section{B. Integrasi Nilai-nilai Karakter Matematika dalam Pengembangan Rencana Pelaksanaan Pembelajaran (RPP)}


Dalam pembelajaran matematika hendaknya guru, peneliti pendidikan, dan desainer instruksional berbagi pengetahuan dan pemahaman untuk meningkatkan pengajaran dan pembelajaran matematika. Guru bekerja untuk membantu siswa belajar; peneliti mempelajari bagaimana orang belajar dan mengajar matematika; dan desainer mengembangkan bahan ajar untuk mendukung guru dan siswa. Setiap komunitas (guru, peneliti, dan desainer) mengembangkan metode dan keahliannya. Sehingga dapat memberikan kontribusi yang banyak kepada dunia pendidikan. Sebagaimana yang diungkapkan oleh Magidson (2005) dalam penelitiannya :

"Within mathematics education, classroom teachers, educational researchers, and instructional designers share the common goals of understanding and improving the teaching and learning of mathematics. Teachers work to help students learn; researchers study how people learn and teach mathematics; and designers develop instructional materials to support teachers and students. Each community (of teachers, of researchers, and of designers) develops its own perspectives, methods, and expertise".

Dari ungkapan tersebut menunjukkan pentingnya kerjasama untuk merancang sebuah desain pembelajaran sehingga guru akan dapat mererapkan model pembelajaran yang efektif. Model pembelajaran yang efektif dengan memperhatikan perencanaan pembelajaran yang dimulai dari penyusunan silabus pembelajaran yang mengukuti prinsip-prinsip penyusunannya dan kemudian dijabarkan dalam RPP yang sesuai dengan prinsip-prinsip penyusunannya. Selanjutnya dalam Standar Proses dinyatakan bahwa pelaksanaan pembelajaran merupakan implementasi dari RPP. Pelaksanaan pembelajaran meliputi kegiatan pendahuluan, kegiatan inti, dan kegiatan penutup. Berdasarkan Standar Proses, muatan dan macam kegiatan pembelajaran yang hendaknya muncul dalam setiap tahap serta alternatif nilai karakter yang dapat ditanamkan dan dikembangkan pada diri siswa.

Rencana Pelaksanaan Pembelajaran (RPP) disusun berdasarkan silabus yang dikembangkan oleh sekolah. RPP secara umum adalah penjabaran silabus yang menggambarkan rencana prosedur dan pengorganisasian pembelajaran untuk mencapai kompetensi dasar yang ditetapkan dalam Standar Isi. RPP digunakan sebagai pedoman guru dalam melaksanakan pembelajaran, baik di kelas, laboratorium, dan/atau lapangan. Seperti yang telah duraikan dalam Standar Proses, setiap guru pada satuan pendidikan berkewajiban menyusun RPP untuk setiap Kompetensi Dasar (KD) secara lengkap dan sistematis dengan tujuan agar pembelajaran berlangsung secara interaktif, inspiratif, menyenangkan, menantang, memotivasi siswa untuk berpartisipasi aktif, serta memberikan ruang yang cukup bagi prakarsa, 
kreativitas, dan kemandirian sesuai dengan bakat, minat, dan perkembangan fisik serta psikologis siswa.

\section{Penutup}

Pengintegrasian nilai-nilai matematika dalam proses pembelajaran matematika melalui pembelajaran kontekstual menjadikan peserta didik tidak hanya menguasai kompetensi yang ditargetkan, juga menjadikan peserta didik mengenal, menyadari, peduli, dan menginternalisasi nilai-nilai serta menjadikannya perilaku yang secara sadar ataupun tidak melakukannya dengan ketulusan dan keikhlasan dalam kehidupan bermasyarakat. Sesuai dengan ajaran dari Ki Hajar Dewantara yaitu "Ing ngarsa sung tulada, ing madya mngun karsa, tut wuri handayani" merupakan dambaan dari perwujudan tujuan pendidikan nasional.

\section{Daftar Pustaka}

Depdiknas. (2006). Peraturan Menteri Pendidikan Nasional Nomor 22 Tahun 2006 tentang Standar Isi Pendidikan Dasar dan Menengah. Jakarta: Depdiknas. Jakarta.

Eliasa, E.I. (2014). "Increasing Values of Teamwork and Responsibility of the Students through Games: Integrating Education Character in Lectures," Procedia - Soc. Behav. Sci., vol. 123, pp. 196-203.

Isnaini, M. Dosen Fakultas Tarbiyah, K. B. Badan Penelitian dan Pengembangan Pendidikan Islam, and F. Tarbiyah IAIN Raden Fatah Palembang, "Internalisasi
Nilai-Nilai Pendidikan Karakter Di Madrasah."

Johnshon, E.B. (2002). Contextual Teaching and learning. California: CROWIN PRESS, INC. California: Crown Press, INC.

Magidson, S. (2005). "Building bridges within mathematics education: Teaching, research, and instructional design," J. Math. Behav., vol. 24, no. 2, pp. 135-169.

Prabowo, A. dan Sidi, P. (2010). "Memahat Karakter Melalui Pembelajaran Matematika," pp. 8-10.

Pusat Pengembangan dan Pemberdayaan Pendidik dan Tenaga Kependidikan. (2011). "Modul Matematika SMP Program BERMUTU”. Yogyakarta.

Sauri, H. Firmansyah Sofyan. (2010). Meretas Pendidikan Nilai, 1st ed. Bandung: Arfindo Raya.

Simon, M. A. (2013). "Issues in theorizing mathematics learning and teaching: $A$ contrast between learning through activity and DNR research programs," J. Math. Behav.

Sumantri, E. (2010). "Pendidikan karakter sebagai pendidikan nilai: Tinjauan Filosofis, Agama, dan budaya. Makalah pada seminar Nasional Pendidikan Nilai-Karakter,".

UU. (2003). UU RI Nomor 20 Tahun 2003 Tentang Sistem Pendidikan Nasional Depdiknas. Jakarta.

Zubaidi. (2011). Desain Pendidikan Karakter. Jakarta: Prenada Media Group. 